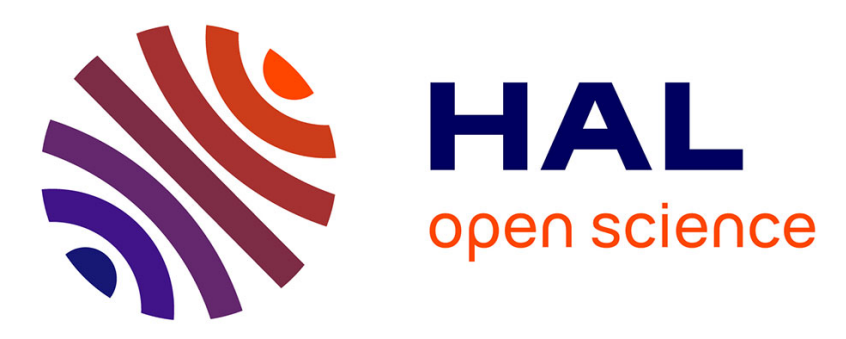

\title{
Growth retardation (stunting) in Coho salmon: Plasma hormone levels in stunts in seawater and after transfer to freshwater
}

Graham Young, Patrick Prunet, Tsuyoshi Ogasawara, Tetsuya Hirano, Howard A. Bern

\section{To cite this version:}

Graham Young, Patrick Prunet, Tsuyoshi Ogasawara, Tetsuya Hirano, Howard A. Bern. Growth retardation (stunting) in Coho salmon: Plasma hormone levels in stunts in seawater and after transfer to freshwater. Aquaculture, 1989, 82 (1-4), pp.269-278. 10.1016/0044-8486(89)90414-6 . hal-02728662

\section{HAL Id: hal-02728662 \\ https://hal.inrae.fr/hal-02728662}

Submitted on 2 Jun 2020

HAL is a multi-disciplinary open access archive for the deposit and dissemination of scientific research documents, whether they are published or not. The documents may come from teaching and research institutions in France or abroad, or from public or private research centers.
L'archive ouverte pluridisciplinaire HAL, est destinée au dépôt et à la diffusion de documents scientifiques de niveau recherche, publiés ou non, émanant des établissements d'enseignement et de recherche français ou étrangers, des laboratoires publics ou privés. 


\title{
Growth Retardation (Stunting) in Coho Salmon: Plasma Hormone Levels in Stunts in Seawater and After Transfer to Fresh Water
}

\author{
GRAHAM YOUNG ${ }^{1,4}$, PATRICK PRUNET $^{2}$, TSUYOSHI OGASAWARA ${ }^{3}$, \\ TETSUYA HIRANO ${ }^{3}$ and HOWARD A. BERN ${ }^{1}$ \\ ${ }^{1}$ Department of Integrative Biology and Cancer Research Laboratory and Bodega Marine \\ Laboratory, University of California, Berkeley, CA 94720 (U.S.A.) \\ ${ }^{2}$ Laboratoire de Physiologie des Poissons, INRA, Campus de Beaulieu, Rennes (France) \\ ${ }^{3}$ Ocean Research Institute, University of Tokyo, Nakano, Tokyo (Japan) \\ ${ }^{4}$ Department of Zoology, University of Otago, P.O. Box 56, Dunedin (New Zealand)
}

\section{ABSTRACT}

Young, G., Prunet, P., Ogasawara, T., Hirano, T. and Bern, H.A., 1989. Growth retardation (stunting) in coho salmon: plasma hormone levels in stunts in seawater and after transfer to fresh water. Aquaculture, 82: 269-278.

Plasma levels of prolactin (PRL), growth hormone (GH), cortisol, thyroxine and triidothyronine were measured in normally-growing seawater (SW) and freshwater (FW) smolts and in animals which had stunted after premature transfer to SW. PRL levels were highest in FW animals and there was no difference between SW stunts and smolts. GH levels were 4-5-fold higher in stunts than in FW or SW smolts. Thyroid hormones and cortisol were significantly lower in stunts. Interrenal activity, assessed in vitro, was depressed in stunts. Transfer of stunts into FW for 3 weeks resulted in a normalization of plasma hormone levels. The results are discussed in relation to the possible causes of stunting and the involvement of the endocrine system in growth retardation.

\section{INTRODUCTION}

The phenomenon of growth retardation (stunting) of coho salmon after transfer to seawater (SW) net pens has received sporadic attention for at least a decade (see Clarke and Nagahama, 1977; Bern, 1978). Premature introduction into SW, before completion of the parr-smolt transformation, or transfer to SW in the postsmoltification period results in poor growth and eventual mortality of a variable but often large percentage of fish. Stunting has been repeatedly linked to osmoregulatory dysfunction as a result of fish entering SW before or after peak hypoosmoregulatory ability has been achieved, although plasma ion profiles generally appear to be normal. Data from Mahnken et al. (1982) indicate that a critical growth path must be maintained in coho 
smolts in SW to avoid parr-reversion and stunting; the ability to maintain growth rate may in turn be dependent on developmental stage.

Morphological studies have classified stunts as pan-hypoendocrine, with a few notable exceptions (Clarke and Nagahama, 1977; Bern, 1978; Nishioka et al., 1982), one of which is the apparently active appearance of pituitary growth hormone (GH) cells. Recently, we demonstrated significantly elevated pituitary and circulating GH levels in stunts (Bolton et al., 1987), and Björnsson et al. (1988) reported a similar situation in Atlantic salmon.

The issue of the involvement of the endocrine system in the initiation of growth retardation is not resolved, partially because of our inability to identify animals which are destined to become stunts at the time of transfer to SW. When animals are clearly identifiable as stunts, they have been in SW for at least 3 months and the endocrine profiles probably reflect the terminal stages of the phenomenon. Stunts transferred back into fresh water (FW) resume apparently normal growth (Clarke and Nagahama, 1977) but no detailed endocrinological and physiological studies have been made on these animals. This is unfortunate, as tracing the events that occur during the reversal of stunting may provide clues as to the initial endocrine events related to growth retardation. In the present study, as a first step towards this goal, we have documented the circulating levels of several hormones in the stunt in SW and after transfer to FW for 3 weeks. In addition, the activity of the interrenal gland in stunted and normally-growing coho in $\mathrm{SW}$ was assessed.

\section{MATERIALS AND METHODS}

\section{Animals}

Yearling coho salmon raised at Trinity (brood year 1984) and Iron Gate Hatchery (brood year 1985) (California Department of Fish and Game) were maintained at Bodega Marine Laboratory in 1000-l concrete tanks which were fitted with viewing windows and supplied with filtered pond water $\left(12-14^{\circ} \mathrm{C}\right.$, natural photoperiod). Fish were fed Oregon Moist Pellets at a ration of $2 \%$ body weight/day. Under these conditions, our animals generally complete the parr-smolt transformation in April. In late February 1985, and in late January 1986 , the freshwater supply to one of the tanks was turned off and the SW supply $(29-32 \%$ ) was turned on, resulting in a complete changeover to SW within $12 \mathrm{~h}$. Fish remained in SW for 4 (1985) or 7 months (1986) before sampling.

\section{Transfer studies (1986)}

Five groups of animals were used in this study: SW stunts, SW smolts (normally-growing animals adapted to SW), FW smolts (normally-growing animals retained in FW) and SW smolts and stunts which were transferred directly into FW and held for 3 weeks. One month before transfer, SW fish were 
separated into stunts and smolts on the basis of body weight, body shape and overall appearance (see Bolton et al., 1987). In all cases, animals were transferred from stock to partitioned areas in each of the FW or SW tanks and were subjected to identical handling. They were fed during the course of the study except that food was withheld on the day of sampling. Both stunts and normally-growing SW-adapted fish ate normally on the day following transfer into FW.

\section{Blood sampling and in vitro techniques}

Animals were netted and quickly anesthetized with MS-222 (see Young, 1986). Blood samples were collected from severed caudal vessels; after centrifugation, plasma was immediately frozen and stored at $-80^{\circ} \mathrm{C}$. Pituitaries were removed and stored at the same temperature.

Head kidneys of eight fish from each group were removed, pooled and minced into fragments of approximately $1 \mathrm{~mm}^{3}$. Details of the method have been published previously (Young, 1986). After washing several times in modified HEPES-buffered Eagle's minimum essential medium (MEM), the tissue was divided into 25 equal portions which were suspended in $1 \mathrm{ml} \mathrm{MEM}$ in tissue culture wells. They were then preincubated at $14^{\circ} \mathrm{C}$ for $3 \mathrm{~h}$. After preincubation, the tissue was washed with MEM and then incubated for $3 \mathrm{~h}$ in hormonefree medium (basal control) or in medium containing a synthetic analog of adrenocorticotropic hormone $\left(\mathrm{ACTH}^{1-24}: 1,5,15,150\right.$, or $1500 \mathrm{ng} / \mathrm{ml}$, five replicates per dose), after which media were removed and frozen at $-20^{\circ} \mathrm{C}$.

\section{Hormone radioimmunoassays}

All radioimmunoassays have been described in detail elsewhere: prolactin (PRL) (Hirano et al., 1985; Prunet et al., 1985); GH (Bolton et al., 1986); cortisol (Young, 1986); thyroxine $\left(\mathrm{T}_{4}\right)$ and triiodothyronine $\left(\mathrm{T}_{3}\right)$ (Dickhoff et al., 1978 with minor modifications reported in Specker and Kobuke, 1987). Pituitaries were processed according to Bolton et al. (1987) before assay.

\section{Statistical analysis}

Data were subjected to one-way or two-way ANOVA and Student-NewmanKeuls' multiple range test using CRISP version 3.05A software (Crunch, San Francisco, CA) and an IBM personal computer.

\section{RESUITS}

\section{5 study (Table 1)}

Plasma GH levels and GH content of the pituitary in stunts and smolts from this study have been reported elsewhere, as have data on body weight and body length (Bolton et al., 1987). Plasma PRL levels were significantly higher $(P<0.01)$ in normally-growing FW fish than in SW stunts and smolts but not 


\section{TABLE 1}

Endocrine status of coho salmon stunts and smolts (1985)

\begin{tabular}{lccc}
\hline & Freshwater smolt & Seawater smolt & Seawater stunt \\
\hline Pituitary prolactin** & $529.7 \pm 140.5^{\mathrm{a}}$ & $339.1 \pm 43.4^{\mathrm{a}}$ & $121.5 \pm 17.5^{\mathrm{b}}$ \\
$\quad(\mathrm{ng} /$ pituitary) & $(8)$ & $(10)$ & $(10)$ \\
Pituitary prolactin & $287.5 \pm 72.9^{\mathrm{a}}$ & $211.0 \pm 29.3^{\mathrm{a}}$ & $142.0 \pm 17.5^{\mathrm{a}}$ \\
$\quad\left(\mathrm{ng} /\right.$ mg pituitary) $^{*}$ & $(8)$ & $(10)$ & $(10)$ \\
Plasma prolactin** & $2.7 \pm 0.4^{\mathrm{a}}$ & $1.0 \pm 0.1^{\mathrm{b}}$ & $0.6 \pm 0.1^{\mathrm{b}}$ \\
$\quad(\mathrm{ng} / \mathrm{ml})$ & $(8)$ & $(8)$ & $(4)$ \\
Plasma thyroxine & $3.3 \pm 0.2^{\mathrm{a}}$ & $3.8 \pm 0.7^{\mathrm{a}}$ & $1.3 \pm 0.3^{\mathrm{b}}$ \\
$\quad(\mathrm{ng} / \mathrm{ml})$ & $(8)$ & $(10)$ & $(10)$ \\
Plasma triiodothyronine & $2.2 \pm 0.2^{\mathrm{a}}$ & $1.9 \pm 0.2^{\mathrm{a}}$ & $0.9 \pm 0.1^{\mathrm{b}}$ \\
$\quad(\mathrm{ng} / \mathrm{ml})$ & $(8)$ & $(10)$ & $(10)$ \\
Plasma cortisol & $13.0 \pm 2.3^{\mathrm{a}}$ & $20.6 \pm 4.3^{\mathrm{a}}$ & $2.8 \pm 0.7^{\mathrm{b}}$ \\
$\quad(\mathrm{ng} / \mathrm{ml})$ & $(8)$ & $(10)$ & $(10)$ \\
\hline
\end{tabular}

Values in parentheses are numbers of samples. Data presented as mean \pm s.e.m.

Values sharing a common superscript do not vary significantly.

Level of significance: ${ }^{*} P<0.05$; ${ }^{* *} P<0.01$.

See Bolton et al. (1987) for weights, lengths and growth hormone data.

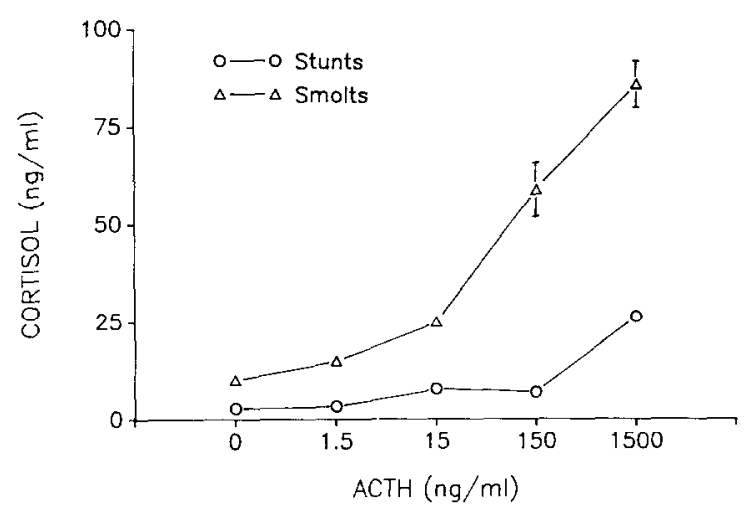

Fig. 1. Cortisol production in vitro by interrenal tissue of seawater coho smolts and stunts. Tissue was preincubated for $3 \mathrm{~h}$, washed, and then challenged with $0,1.5,15,150$ or $1500 \mathrm{ng} / \mathrm{ml}$ $\mathrm{ACTH}^{1-24}$ for $3 \mathrm{~h}$. Media were then analyzed for cortisol by radioimmunoassay. Data presented as mean \pm s.e.m. s.e.m. bars not shown are less than the value taken up by the symbol of their respective mean.

significantly different between SW smolts and SW stunts. Pituitary PRL levels on a per mg tissue basis did not vary significantly, although stunt values appeared to be lower than those of FW smolts $(P<0.1)$; on a per pituitary basis, stunt pituitaries contained significantly less PRL than FW smolt pituitaries $(P<0.01)$, and SW smolt pituitaries appeared to contain less PRL than FW smolts and more than SW stunts, although not significantly so $(P<0.1)$. 
Plasma levels of cortisol $(P<0.05), \mathrm{T}_{4}$ and $\mathrm{T}_{3}(P<0.01)$ were significantly lower in stunts than in SW and FW smolts.

The in vitro responsiveness of interrenal tissue from stunts and SW smolts is shown in Fig. 1. Two-way ANOVA demonstrated a significant difference $(P<0.01)$ between the dose-response curves obtained, and at each dose of $\mathrm{ACTH}$, the interrenal tissue of smolts secreted a significantly greater amount $(P<0.05)$ of cortisol than did tissue from stunts.

\section{6 study}

Body weights, body lengths, and plasma levels of various hormones in animals subjected to transfer to FW for 3 weeks are shown in Table 2 . Body weights and lengths of SW stunts were significantly lower $(P<0.01)$ than those of FW and SW smolts. No significant increase in body weight or length occurred in stunts which were exposed to FW for 3 weeks. GH levels were significantly higher $(P<0.01)$ in stunts in SW than in all other groups. Transfer of stunts into FW resulted in a normalization of $\mathrm{GH}$ levels and there were no other significant differences between FW smolts and SW smolts and stunts which were transferred to FW. Plasma PRL levels in all groups of FW fish were significantly higher $(P<0.05)$ than in $\mathrm{SW}$ groups, with the exception of SW smolts

\section{TABLE 2}

Body weights and lengths and plasma hormone levels of coho salmon stunts and smolts in seawater and after transfer to freshwater for 3 weeks

\begin{tabular}{|c|c|c|c|c|c|}
\hline & SW stunt & SW smolt & $\mathrm{SW} \underset{\text { stunt }}{\longrightarrow} \mathrm{FW}$ & $\mathrm{SW} \underset{\text { smolt }}{\longrightarrow} \mathrm{FW}$ & FW smolt \\
\hline $\begin{array}{l}\text { Body weight** } \\
\text { (g) }\end{array}$ & $\begin{array}{l}23.7 \pm 1.0^{\mathrm{a}} \\
(14)\end{array}$ & $\begin{array}{c}78.2 \pm 2.9^{b} \\
(15)\end{array}$ & $\begin{array}{c}27.9 \pm 1.3^{\mathrm{a}} \\
(12)\end{array}$ & $\begin{array}{c}68.8 \pm 7.2^{b} \\
(8)\end{array}$ & $\begin{array}{c}82.5 \pm 9.4^{\mathrm{b}} \\
(7)\end{array}$ \\
\hline $\begin{array}{l}\text { Body length** } \\
(\mathrm{cm})\end{array}$ & $\begin{array}{l}14.7 \pm 0.2^{\mathrm{a}} \\
(14)\end{array}$ & $\begin{array}{c}19.1 \pm 0.2^{b} \\
(15)\end{array}$ & $\begin{array}{c}14.3 \pm 0.2^{\mathrm{a}} \\
(12)\end{array}$ & $\begin{array}{c}18.1 \pm 0.5^{b} \\
(8)\end{array}$ & $\begin{array}{c}18.6 \pm 2.6^{\mathrm{b}} \\
(7)\end{array}$ \\
\hline $\begin{array}{l}\text { Plasma } \mathrm{GH}^{* *} \\
(\mathrm{ng} / \mathrm{ml})\end{array}$ & $\begin{array}{l}164.6 \pm 11.9^{\mathrm{a}} \\
(14)\end{array}$ & $\begin{array}{l}46.9 \pm 4.8^{\mathrm{b}} \\
\quad(15)\end{array}$ & $\begin{array}{l}37.8 \pm 8.4^{b} \\
(12)\end{array}$ & $\begin{array}{c}14.1 \pm 2.1^{\mathrm{b}} \\
(8)\end{array}$ & $\begin{array}{c}24.6 \pm 1.5^{b} \\
(7)\end{array}$ \\
\hline $\begin{array}{l}\text { Plasma PRL* } \\
\text { (ng/ml) }\end{array}$ & $\begin{array}{c}2.0 \pm 0.2^{\mathrm{ab}} \\
(7)\end{array}$ & $\begin{array}{c}2.0 \pm 0.2^{\mathrm{ab}} \\
(13)\end{array}$ & $\begin{array}{c}4.0 \pm 1.0^{\mathrm{c}} \\
(5)\end{array}$ & $\begin{array}{c}3.1 \pm 0.3^{\mathrm{bc}} \\
(7)\end{array}$ & $\begin{array}{c}3.7 \pm 0.5^{\mathrm{c}} \\
(7)\end{array}$ \\
\hline $\begin{array}{l}\text { Plasma }{ }^{* * *} \\
\quad(\mathrm{ng} / \mathrm{ml})\end{array}$ & $\begin{array}{l}1.3 \pm 0.2^{\mathrm{a}} \\
(10)\end{array}$ & $\begin{array}{l}4.3 \pm 0.3^{b} \\
(13)\end{array}$ & $\begin{array}{c}4.5 \pm 0.6^{\mathrm{b}} \\
(7)\end{array}$ & $\begin{array}{c}4.7 \pm 0.3^{b} \\
(8)\end{array}$ & $\begin{array}{l}5.9 \pm 0.6^{b} \\
(6)\end{array}$ \\
\hline $\begin{array}{l}\text { Plasma } \mathrm{T}_{3}^{*} \\
\quad(\mathrm{ng} / \mathrm{ml})\end{array}$ & $\begin{array}{l}1.3 \pm 0.2^{\mathrm{a}} \\
(6)\end{array}$ & $\begin{array}{l}3.2 \pm 0.2^{\mathrm{bc}} \\
(13)\end{array}$ & $\begin{array}{c}2.1 \pm 0.2^{\mathrm{d}} \\
(7)\end{array}$ & $\begin{array}{c}2.8 \pm 0.2^{\text {bd }} \\
(8)\end{array}$ & $\begin{array}{c}3.7 \pm 0.5^{\mathrm{c}} \\
(5)\end{array}$ \\
\hline $\begin{array}{l}\text { Plasma cortisol }{ }^{* *} \\
\quad(\mathrm{ng} / \mathrm{ml})\end{array}$ & $\begin{array}{l}19.6 \pm 3.2^{\mathrm{a}} \\
\quad(8)\end{array}$ & $\begin{array}{l}32.9 \pm 3.7^{\mathrm{b}} \\
(12)\end{array}$ & $\begin{array}{c}4.8 \pm 1.2^{c} \\
(8)\end{array}$ & $\begin{array}{c}3.6 \pm 0.9^{c} \\
(7)\end{array}$ & $\begin{array}{c}5.0 \pm 1.4^{c} \\
(7)\end{array}$ \\
\hline
\end{tabular}

SW, seawater-adapted; FW, freshwater-adapted; $\mathrm{GH}$, growth hormone; PRL, prolactin; $\mathrm{T}_{4}$, thyroxine; $T_{3}$, triiodothyronine.

Values in parentheses are number of samples. Data presented as mean \pm s.e.m.

Values sharing a common superscript do not vary significantly.

Level of significance: ${ }^{*} P<0.05 ;{ }^{*} P<0.01$. 
in FW. There were no significant differences in plasma PRL levels amongst groups of fish in FW, or amongst groups in $\mathrm{SW}$. Plasma levels of $\mathrm{T}_{4}$ and $\mathrm{T}_{3}$ were significantly lower $\left(\mathrm{T}_{4}, P<0.01 ; \mathrm{T}_{3}, P<0.05\right)$ in $\mathrm{SW}$ stunts than in all other groups; transfer of stunts back to FW resulted in levels which did not differ significantly from those of normally-growing animals, with the exception of $\mathrm{T}_{3}$ levels when compared with FW smolts. Plasma cortisol levels in SW stunts were significantly lower $(P<0.01)$ than those in SW smolts; transfer of both groups into FW led to a significant decrease $(P<0.01)$ in circulating cortisol.

\section{DISCUSSION}

Folmar et al. (1982) reported that circulating $\mathrm{T}_{4}$ was depressed in stunts although plasma $T_{3}$ levels appeared normal, in agreement with morphological signs of severely depressed thyroid gland activity. The present study confirms the earlier report of reduced circulating $\mathrm{T}_{4}$ in coho stunts; however, in contrast to the finding of Folmar et al. (1982), plasma $T_{3}$ levels were significantly reduced in stunts. Essentially normal plasma thyroid hormone levels were seen after transfer of stunts back into $\mathrm{FW}$ for 3 weeks. Depressed plasma $\mathrm{T}_{4}$ levels were also found in Atlantic salmon which failed to grow in SW net pens (Björnsson et al., 1988).

Ultrastructural examination of the stunt interrenal revealed signs of dysfunction such as reduced smooth endoplasmic reticulum, reduced cell membrane infolding, and mitochondria with disrupted cristae (Nishioka et al., 1982). In the present study, these abnormalities are reflected in the limited ability of the interrenal tissue of stunts to respond to ACTH. The status of circulating cortisol in stunts is less clear: in the 1985 study, plasma cortisol levels were severely depressed in stunts; in 1986 , cortisol levels were not depressed to the same extent and both stunts and smolts in SW displayed levels which were significantly higher than those of the FW groups. Other data accumulated over the past few years suggests that reduced plasma cortisol levels is a common, although not completely consistent feature of this phenomenon (Young, unpublished data). The differences may be related to when, in the progression of stunting, the animals are sampled. However, data on interrenal responsiveness have proven to be consistent in consecutive years (Young, unpublished data), and transfer of SW stunts to FW leads to a complete restoration of interrenal activity (Young, in preparation).

Ultrastructural studies on pituitary PRL cells in coho adapted to FW or SW (Clarke and Nagahama, 1977; Nishioka et al., 1982) are in accord with the present observations that plasma PRL levels vary with the environmental salinity to which animals are adapted. Changes in plasma PRL levels during acclimation of coho to SW have been reported elsewhere (Young et al., 1989) and the present data on PRL levels after return of fish to FW are consistent 
with a role for PRL in adaptation to a hypoosmotic environment (but note the lower PRL levels in SW smolts transferred to FW), although this hormone does not seem to be required for FW survival (see Nishioka et al., 1987).

The present data confirm the previous report that plasma GH levels are 45 -fold higher in stunts in SW in comparison to normally-growing fish in SW or in FW (Bolton et al., 1987), in line with the ultrastructural indications of active pituitary GH cells in these animals (Clarke and Nagahama, 1977; Nishioka et al., 1982). Transfer of stunts back into FW resulted in a normalization of plasma $\mathrm{GH}$ levels.

Thus, readaptation of coho stunts to a hypoosmotic environment resulted in a restoration of several components of the endocrine system identified as compromised in the SW stunts. Although body weight gains were not apparent after this relatively short period in FW, Clarke and Nagahama (1977) reported increased condition factor in stunts returned to FW for 4 months. Further studies examining the time-course of endocrine changes during the adaptation of stunts to FW should help identify the sequence of events involved in the restoration of the endocrine system.

In the study of the endocrine physiology of the coho stunt, caution is needed in attempting to link any one of the endocrine abnormalities to the cause of stunting. Although in our experience coho stunts do eat and do pursue food, and aggressively so when separated from their normally-growing counterparts, they may still be suffering from caloric deficiency since intestinal nutrient uptake is compromised in the stunt (Collie, 1985). However, it should be noted that Woo et al. (1978) stated that "starvation is unlikely to be the cause of stunting as biochemical analyses showed that there are still appreciable amounts of glycogen and fat in the storage tissues". Nonetheless, care must be taken in distinguishing between endocrine abnormalities directly associated with the stunting phenomenon and those which may appear as a secondary response to reduced caloric intake.

Fasting results in a general depression of the thyroid system in salmonids (see Leatherland, 1982; Shields and Eales, 1986). However, it is well documented that depressed thyroid activity occurs relatively rapidly after introduction of coho into SW early in the parr-smolt transformation (see Specker and Kobuke, 1987).

The effects of starvation and fasting on plasma cortisol levels have apparently been reported in only two studies: Milne et al. (1979) found no effect in rainhow trout, whereas Barton et al. (1988) reported a decrease in resting plasma cortisol levels in chinook salmon, although there was no appreciable difference between fed and fasted animals in terms of their plasma cortisol levels after a handling stress, suggesting that interrenal responsiveness was not grossly affected in fasted fish. In tetrapod vertebrates, the effects of protein and/or caloric malnutrition in juveniles and adults are consistent with enhanced adrenal function (see Carsia et al., 1988). These results are clearly in 
contrast to our observations on the stunt interrenal which was virtually unresponsive to ACTH. The deficiency of the stunt interrenal appears to be specifically at the intracellular level, most strikingly affecting mitochondria; at the light-microscope level, differences in cell size or cell number between stunts and normally-growing animals are not apparent (Nishioka et al., 1982). This suggests that hypoactivity of the stunt interrenal may be the result of a deficient steroid-biosynthetic pathway and is a more specific effect than would be expected if hypoactivity occurred as a result of malnutrition, where gross changes in cell size and number might be expected.

GH levels are consistently elevated in stunted coho salmon. Bolton et al. (1987) discussed the possible link with reduced caloric intake and suggested that the abnormalities seen in the area of the neurohypophysis associated with control of pituitary GH cells, and the evidence of reduced GH-binding by liver, gill and kidney point to the cause of elevated plasma GH levels as being more complex than a result of lowered caloric intake. Nonetheless, dramatically elevated plasma GH levels have been reported in rainbow trout deprived of food for 3 weeks (Wagner and McKeown, 1986).

Although some of the endocrine changes associated with stunting may be due in part to the impaired intestinal ability to absorb nutrients, the normalization of plasma hormone levels within 3 weeks after transfer of stunts to FW, in the absence of body weight changes, strongly suggests that the endocrine system mediates the deleterious effects of the hyperosmotic environment on the stunt. Two non-exclusive hypotheses have been put forward to explain stunting: Woo et al. (1978) postulated that stunting results from abnormalities in protein and carbohydrate metabolism, and further suggested that osmotic and ionic homeostasis may be maintained at such a metabolic cost that only a small proportion of food intake is available for growth. More recently, Marini and Kerstetter (1982) showed that intracellular liver $\mathrm{K}^{+}$levels are elevated in stunts. Kerstetter (1988, in Kerstetter and Krueger, 1989, and personal communication) has argued that $\mathrm{K}^{+}$-loading may result from increased hepatocyte $\mathrm{Na}^{+}-\mathrm{K}^{+}$-ATPase activity and dysfunction in SW absorption from the gut (cf. Collie and Bern, 1982), leading to abnormally high salt loads in the hepatic portal system. The link between these two hypotheses may lie in the possibility that high $\mathrm{K}^{+}$could impair the ability of liver cells to produce somatomedins (cf. Lindahl et al., 1985) in response to GH. This could conceivably lead to metabolic problems, considering the roles of $\mathrm{GH}$, cortisol and thyroid hormones in metabolism (see Sheridan, 1987) and their potentially complex functional interrelationships. In this context, it is worth noting the evidence for insulin deficiency in stunts (Bern, 1978; Plisetskaya et al., 1988). Introduction of coho into SW when they are not able to hypoosmoregulate efficiently may therefore directly induce changes at the level of the liver (and possibly other tissues) which could lead, via endocrine changes, to metabolic 
problems. One consequence of this would be for animals to fall below the critical growth path described by Mahnken et al. (1982).

\section{ACKNOWLEDGEMENTS}

We thank Dr. Jonathan P. Bolton for assaying GH levels, Richard J. Lin, Kevin Mark, Kenneth Takamura and Brian Williams for expert technical assistance, and Drs. Theodore H. Kerstetter, Stephen D. McCormick and Richard S. Nishioka for helpful discussion. This work is a result of work sponsored in part by NOAA, National Sea Grant College Program, under Grant NA85AAD-SG140, through the California Sea Grant College Program, in part by the California State Resources Agency, Project R/F-117 and in part by NSF Grant DCB 84-05249. The U.S. Government is authorized to produce and distribute reprints for government purposes.

\section{REFERENCES}

Barton, B.A., Schreck, C.B. and Fowler, L.G., 1988. Fasting and diet content affect stress-induced changes in plasma glucose and cortisol in juvenile chinook salmon. Prog. Fish. Cult., 50: 1622.

Bern, H.A., 1978. Endocrinological studies on normal and abnormal salmon smoltification. In: P.J. Gaillard and H.H. Boer (Editors), Comparative Endocrinology. Elsevier, Amsterdam, pp. 97-100.

Björnsson, B.T., Ogasawara, T., Hirano, T., Bolton, J.P. and Bern, H.A., 1988. Elevated growth hormone levels in stunted Atlantic salmon, Salmo salar. Aquaculture, 73: 275-281.

Bolton. J.P., Takahashi, A., Kawauchi, H., Kubota, J. and Hirano, T., 1986. Development and validation of a salmon growth hormone radioimmunoassay. Gen. Comp. Endocrinol., 62: 230238.

Bolton, J.P., Young, G., Nishioka, R.S., Hirano, T. and Bern, H.A., 1987. Plasma growth hormone levels in normal and stunted yearling coho salmon, Oncorhynchus kisutch. J. Exp. Zool., 242: 379-382.

Carsia. R.V., Weber, H. and Lauterio, T.J., 1988. Protein malnutrition in the domestic fowl induces alterations in adrenocortical function. Endocrinology, 122: 673-680.

Clarke, W.C. and Nagahama, Y., 1977. Effects of premature transfer to sea water on juvenile coho salmon (Oncorhynchus kisutch). Can. J. Zool., 55: 1620-1630.

Collie, N.L., 1985. Intestinal nutrient transport in coho salınon (Oncorhynchus kisulch) and the effects of development, starvation, and seawater adaptation. J. Comp. Physiol. B, 156: 163174 .

Collie, N.L. and Bern, H.A., 1982. Changes in intestinal fluid transport associated with smoltification and seawater adaptation in coho salmon. Oncorhynchus kisutch (Walbaum). J. Fish Biol, 21: 337-348.

Dickhoff, W.W., Folmar, L.C. and Gorbman, A., 1978. Changes in plasma thyroxine during smoltification of coho salmon, Oncorhynchus kisutch. Gen. Comp. Endocrinol., 36: 229-232.

Folmar, L.C., Dickhoff, W.W., Mahnken, C.V.W. and Waknitz, F.W., 1982. Stunting and parrreversion during smoltification of coho salmon (Oncorhynchus kisutch). Aquaculture, 28: 91 . 104. 
Hirano, T., Prunet, P., Kawauchi, H., Takahashi, A., Ogasawara, T., Kubota, J., Nishioka, R.S., Bern, H.A., Takada, K. and Ishii, S., 1985. Development and validution of a salmon prolactin radioimmunoassay. Gen. Comp. Endocrinol., 59: 266-276.

Kerstetter, T.H., 1988. Stunting in coho salmon: an investigation of apparent abnormalities in ion regulation. California Sea Grant College Program, 1986-1987, Annual Report. Institute of Marine Resources, La Jolla (in press).

Kerstetter, T.H. and Krueger, D., 1989. Elevated liver potassium in juvenile, seawater-adapted coho salmon. Aquaculture, 82: 378-379 (Abstract).

Leatherland, J.F., 1982. Environmental physiology of the teleostean thyroid gland: a review. Environ. Biol. Fish, 7: 83-110.

Lindahl, K.I., Sara, V., Fridberg, G. and Nishimiya, T., 1985. The presence of somatomedin in the Baltic salmon, Salmo salar, with special reference to smoltification. Aquaculture, 45: 177 184.

Mahnken, C., Prentice, E., Waknitz, W., Monan, G., Sims, C. and Williams, J., 1982. The application of recent smoltification research to public hatchery releases: an assessment of size/time requirements for Columbia River hatchery coho salmon (Oncorhynchus kisutch). Aquaculture, 28: 251-268.

Marini, G. and Kerstetter, 'T.H., 1982. Intracellular electrolyte regulation in freshwater and seawater adapted coho salmon. Aquaculture, 28: 75-80.

Milne, R.S., Leatherland, J.F. and Holub, B.J., 1979. Changes in plasma thyroxine, triiodothyronine and cortisol associated with starvation in rainbow trout (Salmo gairdneri). Environ. Biol. Fish, 4: 185-190.

Nishioka, R.S., Bern, H.A., Lai, K.V., Nagahama, Y. and Grau, E.G., 1982. Changes in the endocrine organs of coho salmon during normal and abnormal smoltification - an electron microscope study. Aquaculture, 28: 21-38.

Nishioka, R.S., Richman, N.H., Young, G., Prunet, P. and Bern, H.A., 1987. Hypophysectomy of coho salmon (Oncorhynchus kisutch) and survival in fresh water and in seawater. Aquaculture, 65: 343-352.

Plisetskaya, E.M., Swanson, P., Bernard, M.G. and Dickhoff, W.W., 1988. Insulin in coho salmon (Oncorhynchus kisutch) during the parr to smolt transformation. Aquaculture, 72: 151-164.

Prunet, P., Boeuf, G. and Houdebine, L.M., 1985. Plasma and pituitary prolactin levels in rainbow trout during adaptation to different salinities. J. Exp. Zool., 235: 187-196.

Sheridan, M., 1987. Effects of thyroxin, cortisol growth hormone and prolactin on lipid metabolism of coho salmon (Oncorhynchus kisutch). Gen. Comp. Endocrinol., 65: 220-238.

Shiclds, C.A. and Eales, J.G., 1986. Thyroxine 5' -monodeiodinase activity in hepatocytes of rainbow trout, Salmo gairdneri: distribution, effects of starvation, and exogenous inhibitors. Gen. Comp. Endocrinol., 63: 334-343.

Specker, J.L. and Kobuke, L., 1987. Seawater-acclimation and the thyroid response to thyrotropin in juvenile coho salmon (Oncorhynchus kisutch). J. Exp. Zool., 241: 327-332.

Wagner, G.F. and McKeown, B.A., 1986. Development of a salmon growth hormone radioimmunoassay. Gen. Comp. Endocrinol., 62: 452-458.

Woo, N.Y.S., Bern, H.A, and Nishioka, R.S., 1978. Changes in body composition associated with smoltification and premature transfer to seawater in coho salmon (Oncorhynchus kisutch) and king salmon ( $O$. tshouytscha). J. Fish Biol., 13: 421-428.

Young, G., 1986. Cortisol secretion in vitro by the interrenal of coho salmon (Oncorhynchus kisutch) during smoltification: relationship with plasma thyroxine and plasma cortisol. Gen. Comp. Endocrinol., 63: 191-200.

Young, G., Björnsson, B.T., Prunet, P., Lin, R.J. and Bern, H.A., 1989. Smoltification and seawater adaptation of coho salmon, Oncorhynchus kisutch: Plasma prolactin, growth hormone, thyroid hormones and cortisol. Gen. Comp. Endocrinol., 74: 335-345. 